\title{
Effects of Glosses and Involvement Loads on Incidental Vocabulary Acquisition
}

\author{
Shuang Tong \\ North Sichuan College of Preschool Teacher Education, China
}

Keywords: Incidental vocabulary acquisition; Glosses; Involvement load.

\begin{abstract}
The present study aims at exploring the effects of different glosses and involvement loads on incidental vocabulary acquisition among non-English majors. It investigates whether glosses and involvement load would have an effect on the learners' immediate word gain and promote their word knowledge retention. The experiment chooses 96 non-English freshmen at a university in Si Chuan Province. Results indicate that1) the multiple-choice glosses has a better effect on incidental vocabulary acquisition and retention than the single glosses; 2) high involvement loads can contribute to better acquisition and retention; 3)different glosses and involvement loads exert different influences on vocabulary acquisition and retention. Translation task with multiple-choice glosses is the most effective, and reading comprehension task with single glosses is the worst.
\end{abstract}

\section{Introduction}

Vocabulary knowledge is an essential component for language learning, as Read (2000) mentioned: "Words are the basic building blocks of language." [1], so vocabulary learning is central and of great importance to language learners. However, vocabulary learning seems to be difficult for Chinese English learners. Chinese EFL educators have been struggling to seek the most effective way to acquire vocabulary for the Chinese context. The present study tries to make an experimental study on the effect of glosses and involvement loads on IVA in non-English major students teaching. The present author conducts a scientific data analysis of the results, which really reflects that different types of glosses and involvement loads have different impacts on IVA in the field of language teaching, hoping to provide great help for compiling extensive reading textbook and teaching non-English majored students.

\section{Studies on Second Language Incidental Vocabulary Learning}

The widely accepted definition is given by Hulstijn(1992):the learning of vocabulary as the by-product of any activity not explicitly geared to vocabulary learning. He defines intentional vocabulary learning as any activity aiming at committing lexical information to memory[2].

\section{Research Design}

Participants. To make sure all the subjects have identical English proficiency level, the present author chooses ninety-six participants (non-English major students, Grade One from a university in China) whose scores in the National Entrance Examination to College are almost at the same level, a little above or below one hundred scores.

Procedure. The experiment lasts for 4 weeks, and processes in the following 4 steps:

Step 1: A week before the experiment, a vocabulary test is conducted as a pretest to examine 96 students' vocabulary level. They are asked to finish it in 20 minutes. The results, calculated by oneway analysis of variance, indicate that 96 students are equivalent in terms of vocabulary size. Thus 96 students are determined as subjects. 
Step 2: As above mentioned, a pilot study is made among 15 students, who wouldn't take part in the main study, to determine the reading materials and target words.

Step 3: Subjects are divided into 4 groups, reading the same article with no awareness of the following exercises. After 20 minutes, reading comprehension and translation test paper are handed out, which need 20 minutes to finish. After the collection of reading materials and test paper, the target word test paper is handed out. In order to avoid subjects' too much attention on vocabulary but neglect the reading comprehension, they are uninformed of the vocabulary test. The test paper should be completed in 20 minutes.

Step4: A week later, they take part in the delayed test containing the same target words with immediate test. To eliminate the inferring influence of immediate test, the order of target words is adjusted in another way. The delayed test aimes at examining whether target words would be retained. During two tests, subjects are not allowed to discussion, use dictionary and consult teachers. Time is distributed at students' normal class time to conduct the same test.

\section{Results and Discussion}

All the data are collected from the vocabulary test, they are analyzed by SPSS 13.0, in which involvement loads and glosses are recognized as two variables. The present author examines the results from two aspects: the comprehensive discussion respectively on the effect of different involvement loads and glosses for each group, the comparison of two factors' impact on subjects' IVA. Followed by the results, a discussion of each finding is presented in the light of quality and quantity analysis.

The Impacts of Different Types of Glosses on IVA

The results of two experimental groups, Group 3 and 4 are reported as follows.

T-test Results for Immediate Test

Table 1 Descriptive Statistics of Immediate Test

\begin{tabular}{|c|c|c|c|c|c|}
\hline & $\begin{array}{c}\text { GROU } \\
\mathrm{P}\end{array}$ & $\mathrm{N}$ & Mean & Std. Deviation & $\begin{array}{c}\text { Std. Error } \\
\text { Mean }\end{array}$ \\
\hline Immediate & 3 & 24 & 19.87 & 4.74 & .3137 \\
& 4 & 24 & 24.89 & 4.77 & .3241 \\
\hline
\end{tabular}

Table 2 Independent Sample Test for Immediate Test

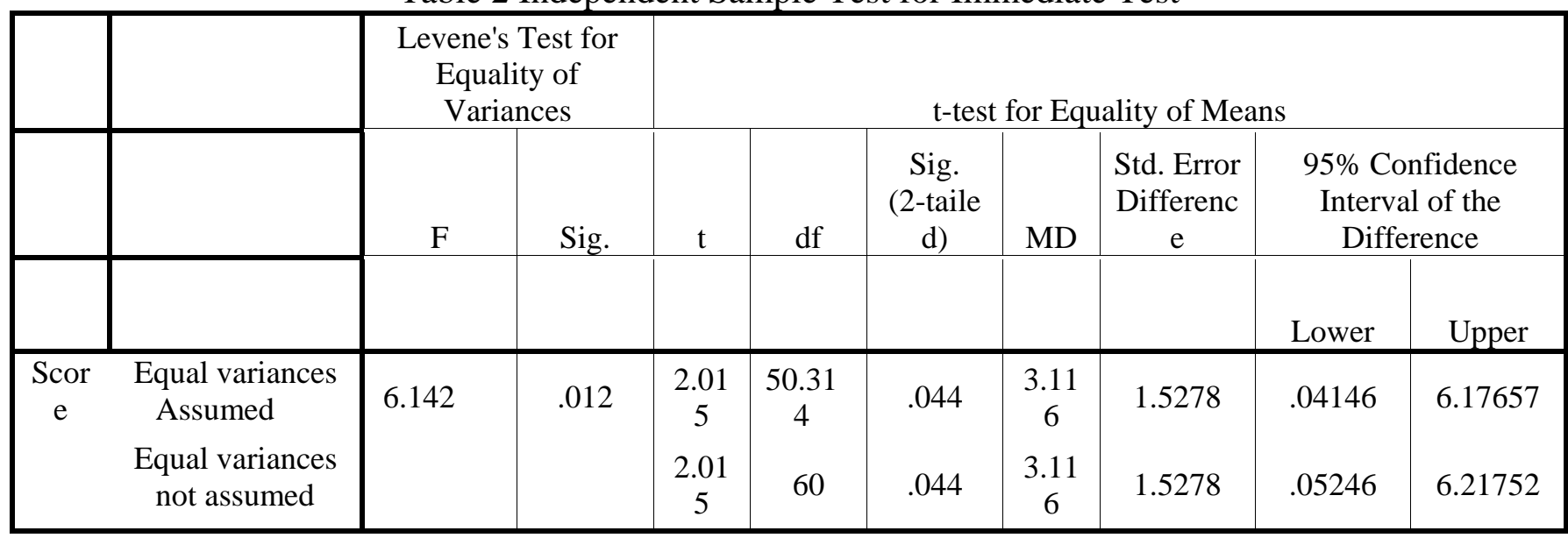

T-test Results for Delayed Test

Table 3 Descriptive Statistics of Delayed Test

\begin{tabular}{|c|c|c|c|c|c|}
\hline & $\begin{array}{c}\text { GROU } \\
\mathrm{P}\end{array}$ & $\mathrm{N}$ & Mean & Std. Deviation & $\begin{array}{c}\text { Std. Error } \\
\text { Mean }\end{array}$ \\
\hline Delayed & 3 & 24 & 17.63 & 4.34 & .3276 \\
& 4 & 24 & 20.86 & 5.86 & .3378 \\
\hline
\end{tabular}


Table 4 Independent Sample Test for Delayed Test

\begin{tabular}{|c|c|c|c|c|c|c|c|c|c|c|}
\hline & & \multicolumn{2}{|c|}{$\begin{array}{c}\text { Levene's Test for } \\
\text { Equality of } \\
\text { Variances }\end{array}$} & \multicolumn{7}{|c|}{ t-test for Equality of Means } \\
\hline & & \multirow[t]{2}{*}{$\mathrm{F}$} & \multirow[t]{2}{*}{ Sig. } & \multirow[t]{2}{*}{$\mathrm{t}$} & \multirow[t]{2}{*}{ df } & \multirow[t]{2}{*}{$\begin{array}{l}\text { Sig. } \\
\text { (2-taile } \\
\text { d) }\end{array}$} & \multirow[t]{2}{*}{ MD } & \multirow[t]{2}{*}{$\begin{array}{c}\text { Std. Error } \\
\text { Differenc } \\
\text { e } \\
\end{array}$} & \multicolumn{2}{|c|}{$\begin{array}{l}\text { 95\% Confidence } \\
\text { Interval of the } \\
\text { Difference }\end{array}$} \\
\hline & & & & & & & & & Lower & Upper \\
\hline $\begin{array}{c}\text { Scor } \\
\text { e }\end{array}$ & $\begin{array}{l}\text { Equal variances } \\
\text { Assumed } \\
\text { Equal variances } \\
\text { not assumed }\end{array}$ & .712 & .388 & $\begin{array}{c}3.34 \\
5 \\
3.34 \\
5\end{array}$ & $\begin{array}{c}60 \\
61.34 \\
4 \\
\end{array}$ & $\begin{array}{l}.003 \\
.003\end{array}$ & $\begin{array}{c}4.43 \\
2 \\
4.43 \\
2\end{array}$ & $\begin{array}{l}1.32495 \\
1.32495\end{array}$ & $\begin{array}{l}1.85735 \\
1.85728\end{array}$ & $\begin{array}{l}7.21658 \\
7.26526\end{array}$ \\
\hline
\end{tabular}

The Impacts of Different Involvement Loads on IVA

The results of two experimental groups, Group 2 and 4 are reported as follows.

T-test Results for Immediate Test

Table 5 Descriptive Statistics of Immediate Test

\begin{tabular}{|c|c|c|c|c|c|}
\hline & & & & & \\
& GROUP & $\mathrm{N}$ & Mean & Std. Deviation & Std. Error Mean \\
\hline Immediate & 2 & 24 & 21.32 & 4.84 & .3207 \\
& 4 & 24 & 24.89 & 4.77 & .3241 \\
\hline
\end{tabular}

Table 6 Independent Sample Test of Immediate Test

\begin{tabular}{|c|c|c|c|c|c|c|c|c|c|c|}
\hline & & \multicolumn{2}{|c|}{$\begin{array}{c}\text { Levene's Test for } \\
\text { Equality of } \\
\text { Variances }\end{array}$} & \multicolumn{7}{|c|}{ t-test for Equality of Means } \\
\hline & & \multirow[t]{2}{*}{$\mathrm{F}$} & \multirow[t]{2}{*}{ Sig. } & \multirow[t]{2}{*}{$\mathrm{t}$} & \multirow[t]{2}{*}{ df } & \multirow[t]{2}{*}{$\begin{array}{c}\text { Sig. } \\
\text { (2-tailed } \\
\text { ) }\end{array}$} & \multirow[t]{2}{*}{ MD } & \multirow[t]{2}{*}{$\begin{array}{c}\text { Std. Error } \\
\text { Differenc } \\
\text { e }\end{array}$} & \multicolumn{2}{|c|}{$\begin{array}{l}\text { 95\% Confidence } \\
\text { Interval of the } \\
\text { Difference }\end{array}$} \\
\hline & & & & & & & & & Lower & Upper \\
\hline $\begin{array}{c}\text { Scor } \\
\text { e }\end{array}$ & $\begin{array}{l}\text { Equal variances } \\
\text { Assumed } \\
\text { Equal variances } \\
\text { not assumed }\end{array}$ & 7.216 & .036 & $\begin{array}{l}2.317 \\
2.317\end{array}$ & $\begin{array}{c}51.73 \\
4 \\
61\end{array}$ & $\begin{array}{l}.038 \\
.038\end{array}$ & $\begin{array}{l}3.376 \\
3.376\end{array}$ & $\begin{array}{l}1.5318 \\
1.5318\end{array}$ & $\begin{array}{l}.05145 \\
.05246\end{array}$ & $\begin{array}{l}6.19513 \\
6.21752\end{array}$ \\
\hline
\end{tabular}

Table 7 Descriptive Statistics of Delayed Test

\begin{tabular}{|c|c|c|c|c|c|}
\hline & GROUP & $\mathrm{N}$ & Mean & Std. Deviation & $\begin{array}{c}\text { Std. Error } \\
\text { Mean }\end{array}$ \\
\hline Delayed & 2 & 24 & 15.62 & 5.01 & .3206 \\
& 4 & 24 & 20.86 & 5.86 & .3378 \\
\hline
\end{tabular}


Table 8 Independent Sample Test of Delayed Test

\begin{tabular}{|c|c|c|c|c|c|c|c|c|c|c|}
\hline & & \multicolumn{2}{|c|}{$\begin{array}{c}\text { Levene's Test for } \\
\text { Equality of } \\
\text { Variances }\end{array}$} & \multicolumn{7}{|c|}{ t-test for Equality of Means } \\
\hline & & \multirow[t]{2}{*}{$\mathrm{F}$} & \multirow[t]{2}{*}{ Sig. } & \multirow[t]{2}{*}{$\mathrm{t}$} & \multirow[t]{2}{*}{$\mathrm{df}$} & \multirow[t]{2}{*}{$\begin{array}{c}\text { Sig. } \\
\text { (2-tailed } \\
\quad \text { ) }\end{array}$} & \multirow[t]{2}{*}{ MD } & \multirow[t]{2}{*}{$\begin{array}{c}\text { Std. Error } \\
\text { Differenc } \\
\text { e }\end{array}$} & \multicolumn{2}{|c|}{$\begin{array}{l}\text { 95\% Confidence } \\
\text { Interval of the } \\
\text { Difference }\end{array}$} \\
\hline & & & & & & & & & Lower & Upper \\
\hline Score & $\begin{array}{l}\text { Equal variances } \\
\text { Assumed } \\
\text { Equal variances } \\
\text { not assumed }\end{array}$ & .832 & .318 & $\begin{array}{l}3.286 \\
3.286\end{array}$ & $\begin{array}{c}61 \\
62.289\end{array}$ & $\begin{array}{l}.012 \\
.012\end{array}$ & $\begin{array}{l}4.382 \\
4.382\end{array}$ & $\begin{array}{l}1.26545 \\
1.26545\end{array}$ & $\begin{array}{l}1.84162 \\
1.85728\end{array}$ & $\begin{array}{l}7.22782 \\
7.26526\end{array}$ \\
\hline
\end{tabular}

\section{The Impacts of Different Involvement Loads and Glosses on IVA}

The Interactive Effects of Different Involvement Loads and Glosses on IVA in Immediate Test

Table 9 Tests of Between-subjects Effects for Immediate Word Test Dependent Variable: Score

\begin{tabular}{|c|c|c|c|c|c|}
\hline Source & $\begin{array}{c}\text { Type All Sum } \\
\text { of Squares }\end{array}$ & df & Mean Square & F & Sig. \\
\hline & & & & & \\
Corrected Model & $2154.031^{\mathrm{a}}$ & 3 & 702.68 & 24.516 & .000 \\
Intercept & 51883.623 & 1 & 52667.3 & 1876.253 & .000 \\
Glosses & 1380.912 & 1 & 1356.72 & 46.985 & .000 \\
Involvement & 678.425 & 1 & 72 & 23.178 & .081 \\
Glosses*Involvement & 71.57 & 1 & 8 & 2.536 & .146 \\
Error & 3568.489 & 128 & 693.156 & & \\
Total & 58937.05 & 129 & 71.89 & & \\
Corrected Total & 5881.345 & 131 & 27.37 & & \\
\hline
\end{tabular}

a.R Aquared $=.368($ Adjusted R Squared $=.341)$ 
Table 10 Comparison of Glosses and Involvement Loads in Immediate Test

\begin{tabular}{|c|c|c|c|c|}
\hline \multirow[b]{2}{*}{ Group } & \multirow[b]{2}{*}{ Mean } & \multirow{2}{*}{$\begin{array}{c}\text { Standard } \\
\text { Error } \\
\end{array}$} & \multicolumn{2}{|c|}{ 95\% Confidence Interva } \\
\hline & & & Lower & Upper \\
\hline Single Glosses and Translation & 19.87 & .3137 & .04146 & 6.17657 \\
\hline $\begin{array}{c}\text { Multiple-choice Glosses and } \\
\text { Translation }\end{array}$ & 24.83 & .3241 & .05246 & 6.21752 \\
\hline $\begin{array}{l}\text { Multiple-choice Glosses and } \\
\text { Answering Questions }\end{array}$ & 21.32 & .3207 & .05145 & 6.19513 \\
\hline $\begin{array}{c}\text { Single Glosses and Answering } \\
\text { Questions }\end{array}$ & 18.91 & .3092 & .04185 & 6.16528 \\
\hline
\end{tabular}

The Interactive Effects of Different Involvement Loads and Glosses on IVA in Delayed Test

Table 11 Tests of Between-subjects Effects for Delayed Word Test

Dependent Variable: Score

\begin{tabular}{|c|c|c|c|c|c|}
\hline Source & $\begin{array}{c}\text { Type All Sum } \\
\text { of Squares }\end{array}$ & $\mathrm{df}$ & Mean Square & $\mathrm{F}$ & Sig. \\
\hline & & & & & \\
Corrected Model & $1968.589^{\mathrm{a}}$ & 3 & 663.263 & 26.383 & .000 \\
Intercept & 34624.425 & 1 & 33713.081 & 1479.252 & .000 \\
Glosses & 546.278 & 1 & 1326.349 & 53.178 & .000 \\
Involvement & 1356.158 & 1 & 552.728 & 24.987 & .075 \\
Glosses*Involvement & 102.261 & 1 & 101.89 & 4.576 & .104 \\
Error & 3045.489 & 128 & 24.327 & & \\
Total & 38623.000 & 129 & & & \\
Corrected Total & 5035.369 & 131 & & & \\
& & & & & \\
\hline
\end{tabular}

a. $\mathrm{R}$ Aquared $=.392($ Adjusted R Squared $=.378)$ 
Table 12 Comparison of Glosses and Involvement Loads in Delayed Test

\begin{tabular}{|c|c|c|c|c|}
\hline \multirow[b]{2}{*}{ Task } & \multirow[b]{2}{*}{ Mean } & \multirow{2}{*}{$\begin{array}{c}\text { Standard } \\
\text { Error }\end{array}$} & \multicolumn{2}{|c|}{ 95\% Confidence Interval } \\
\hline & & & Lower & Upper \\
\hline Single Glosses and Translation & 15.62 & .3206 & 1.84162 & 7.22782 \\
\hline $\begin{array}{l}\text { Multiple-choice Glosses and } \\
\text { Translation }\end{array}$ & 20.86 & .3378 & 1.85728 & 7.26526 \\
\hline $\begin{array}{l}\text { Multiple-choice Glosses and } \\
\text { Answering Questions }\end{array}$ & 17.63 & .3276 & 1.85735 & 7.21658 \\
\hline $\begin{array}{c}\text { Single Glosses and Answering } \\
\text { Questions }\end{array}$ & 14.61 & .3196 & 1.83957 & 7.20746 \\
\hline
\end{tabular}

\section{Conclusion}

The Main Findings

The experiment tends to explore an effective way to enhance learners' reading ability and prove the effect of glosses and involvement loads on IVA through reading. Based on the results and discussion in previous section, the main findings can be concluded as follows:

1 Multiple-choice glosses have more positive effect on incidental vocabulary acquisition than single glosses. Participants who finish translation task on multiple-choice condition can obtain more successful incidental vocabulary acquisition than those who finish translation task on single glosses condition.

2 Different involvement loads have different effects on incidental vocabulary acquisition. According to the results in VKS, it is known that task with high involvement loads get better effect than that of low involvement loads on the retention of incidental vocabulary learning.

3 After reading the passage with different involvement loads and glosses, the participants performed translation task with multiple-choice glosses better than translation task with single glosses, answering questions task with multiple-choice glosses and single glosses.

Implications

Firstly, the present researches prove that IVA can benefit from reading task. It is assumed that for English learners, except for the influencial ways to learn vocabulary like conscious vocabulary leaning, incidental vocabulary acquisition is also a feasible way. However, acknowledging the importance of IVA doesn't mean denying conscious vocabulary learning. Because based on the results of this study, English learners could be encouraged to acquire more vocabulary incidentally, whose main task is to enlarge their vocabulary. Some students find it difficult to increase their vocabulary growth by reciting dictionary. In order to relieve the burden, learners are required to learn vocabulary with the help of glosses. The results of this paper show that providing glosses in reading test can facilitate learners' retention of vocabulary, and multiple-choice glosses conditions is a more effective way than single glosses. Since enlarging vocabulary is a main task in the English learning, teachers should help students to learn more vocabulary. Teachers should choose the reading materials with difficult but glossed target words, and distribute them to students for classroom and extracurricular reading[3].

Secondly, Based on the results of this investigation, it is proved that learner can acquire incidentally vocabulary through reading task with high involvement loads than that with low involvement loads. Thus, teachers and students can design the target words with high involvement loads, which produce a better effect in the process of IVA[4]. These tasks can be designed in the form 
of reading and translation, reading and writing, reading and filling-in. As proposed by Laufer\&Hulstijn(2001), we can design different drills as an aid to learn vocabulary, which depends on the extent of consolidation that we require students to reach[5]. Non-English majored students should be informed of the effects of different involvement loads in the process of incidental vocabulary acquisition, so that they can make a potential choice of relevant tasks.

English teachers can design different reading tasks so that students can find it easier to learn unknown words. They can ask students to finish task with high or low involvement loads according to their teaching objectives and the difficulties of target words. Tasks with high involvement loads are suitable for difficult and important target words, like unknown words, academic vocabulary, idioms and false cognates. Tasks with low involvement loads fit for easy and unimportant words. Furthermore, students should be informed that high involvement loads can facilitate IVA, so that they are capable of choosing appropriate reading tasks and acquire vocabulary easily without the help of teachers.

\section{References}

[1] Read, J. Assessing vocabulary. Cambridge: Cambridge University Press, 2001.

[2] Hulstijn, J. H. Retention of inferred and given word meanings: Experiments in incidental vocabulary learning. In P. J. Arnaud \& H. Béjoint (Eds.), Vocabulary and Applied Linguistics,London: Macmillan,1992, (pp. 113-25).

[3] Duan Shiping, Yan Chensong. Effects of Multiple-choice Gloss on Incidental Vocabulary Acquisition. Foreign Language Teaching and Research, 2004.

[4] Gai Shuhua. A Review of Incidental Vocabulary Acquisition. Journal of PLA University of Foreign Languages,2003.

[5] Hulstijin, J. H. \& Laufer, B. Some empirical evidence for the Involvement Loads Hypothesis in vocabulary acquisition. Language Learning, 51(3), 2001,539-558. 